\title{
The Development and Operation of Offshore Wind Farms in China
}

\author{
Fenghui Yang \\ School of Electrical Engineering \\ shanghai dianji university \\ shanghai, China \\ Email: 1165785066@qqq.com \\ Xiangfeng Zhang \\ School of Electrical Engineering \\ shanghai dianji university \\ shanghai, China \\ Email: 458408672@qq.com
}

\author{
Shuting Chen \\ School of Electrical Engineering \\ shanghai dianji university \\ shanghai, China \\ Email: 1102669275@qq.com \\ Zhijie Wang \\ School of Electrical Engineering \\ shanghai dianji university \\ shanghai, China \\ Email: 864304073@qq.com
}

\begin{abstract}
Wind power is one of the clean energy that has been developed rapidly in China recently. Offshore wind power is paid high attention all over the world for its advantages of less occupation of land, high consumption hours, and rich resources. The authors discuss the offshore wind resources in the coastal areas of China, and feasibility and advantage of offshore wind power development in China in the paper. The key technologies of offshore wind power and operations of wind farm are evaluated, such as, assessment of resources, remote monitoring, transmission interconnection and wind farm site selection.
\end{abstract}

Keywords- offshore wind power; assessment of resources; remote monitoring; transmission interconnection; wind farm site selection(key words)

\section{INTRODUCTION}

Wind energy is a kind of clean and renewable energy. It is abundant and has no pollution to the environment. The onshore wind power technology has been mature after decades of research and developments. In order to make better use of wind power, many countries pay their attention to the offshore wind farm in order to use wind power efficiently. The European grid installation of offshore wind turbines was gross capacity of 1.045 million kilowatts in the first half of 2013. In addition, eighteen wind farms are under construction. The total installed capacity of these wind farms would reach 5.111 million kilowatts if all wind farms were completed[1]. A national conference on offshore wind was held by the national energy administration organization in 2009, and the plan has been launched officially for developing offshore wind power in coastal regions of China. Also, Shanghai Donghai Bridge offshore wind power has begun producing energy since 2009 . This signifies the launch of offshore wind farm construction in China.

The paper is organized as follows. Coastal wind resources assessment in China is introduced, especially in Shanghai, Jiangsu, Shandong and other regions. The feasibility of the construction of offshore wind farm is presented according to the characteristics of the offshore wind power development in China. The development of offshore wind farm, key technology and technical problems are analyzed. Some suggestions for the development of offshore wind farms in China are presented considering the offshore wind farms development in European.

\section{THE DEVELOPMENT OF OFFSHORE WIND FARM}

\section{A. The advantages of offshore wind}

Offshore wind farms are usually constructed along the coast or in the islands with no residents. The offshore wind farms can be divided into intertidal wind farms, offshore wind farms, and deep sea wind farms according to different basic conditions. Oceans with special geographic environment make the offshore wind power resource with the advantages of no occupation of land, long time availability, rich in resources, no consumption of water resources and suitable for large-scale development. Comparing to the onshore wind, the offshore wind development mainly has the following advantages:

1) Offshore wind resource is much higher than the land, which is confirmed by the offshore wind farms that have been built. The wind speed is usually $25 \%$ higher than the coastal land at $10 \mathrm{~km}$ far from the coast.

2) The wind turbulence intensity is small and it has the dominant wind direction. The stability of the unit under the fatigue load is low, which makes the life of the turbines longer.

3) The surface roughness is small, so that the wind shear is small. The wind speed and direction will change when the wind flow through the rough surface or an obstacle. Therefore, the tower needs to be built higher, and it cost much higher.

4) The offshore wind is less affected by noise, landscape, birds or electromagnetic interference problems.

5) The offshore wind farms do not take up of the land and do not involve issues of land requisition. There is no 
doubt that it will attract much attention when the space on land is limited.

6) The development and utilization of the offshore wind power does not cause air pollution and produce any harmful substances. Thus it can reduce greenhouse gas emissions and the environmental value is considerable [2].

At the same time, the offshore wind farm is more close to the load center, comparing with the construction in "three north" area, that is, northwest, northeast, north China's onshore wind. It's easy to consume the electricity produced by the wind and the supporting infrastructure construction is more developed. Therefore, constructing wind farms in the economically developed coastal areas not only has the good economic efficiency, but also can reduce the lack problems of electricity in areas along Yangtze River at a certain extent.

\section{B. The assessment of offshore wind resource}

To plan and develop offshore wind power resource, the available storage of the offshore wind resources, location and area covered must be first considered, which can provide a basis for the distribution of the wind turbine.

For example, Jiangsu offshore wind resources are mainly distributed in offshore waters and coastal land. Research results show that 3.4 million kilowatts capacity can be installed with the range of the land of 50 meters, and the capacity of 13.9 million kilowatts can be installed with the range of the offshore $5 \sim 25$ meters water depth in Jiangsu province. A public bidding was offered for the first time in China in 2010. All of the first four winning projects were from Jiangsu province, as shown in TABLE I.

TABLE I. THE FIRST BATCH WINNING PROJECTS OF JIANGSU

\begin{tabular}{cccc}
\hline No & $\begin{array}{c}\text { Scale/10 } \\
\text { thousand kw }\end{array}$ & Site & $\begin{array}{c}\text { Project } \\
\text { types }\end{array}$ \\
\hline 1 & 30 & Binghai & $\begin{array}{c}\text { offshore } \\
\text { wind farm }\end{array}$ \\
\hline 2 & 30 & Sheyang & $\begin{array}{c}\text { offshore } \\
\text { wind farm }\end{array}$ \\
\hline 3 & 20 & Dafeng & $\begin{array}{c}\text { Intertidal } \\
\text { wind farm }\end{array}$ \\
\hline 4 & 20 & Dongtai & $\begin{array}{c}\text { Intertidal } \\
\text { wind farm }\end{array}$ \\
\hline
\end{tabular}

China's eastern coastal near Shandong province and Shanghai is very rich in offshore wind power resource. There are hundreds of islands along the sea and its coastline is 3100 kilometers according to the assessment from the meteorological bureau of Shandong province. The wind energy density is big and the annual average wind speed is high, which can produce wind energy resources of about 67 million kilowatts. Water near the East China Sea Bridge, east of Chongming island, Nanhui and transverse ShanDong beach for FengFu District east sea can have the wind energy resources reserves of about $3.373 \times 104 \mathrm{Kw}[3]$. The second batch of two million $\mathrm{Kw}$ offshore wind farm franchise bidding project was held in 2011. Shanghai, Jiangsu, Shandong, Zhejiang, and other coastal provinces or cities have launched their own offshore wind project planning. The plan of next ten to twenty years is shown as TABLE II.
TABLE II. INSTALLED CAPACITY IN PLANNING

\begin{tabular}{ccc}
\hline \multirow{2}{*}{ Province or city } & \multicolumn{2}{c}{ Planning capacity (MW) } \\
\cline { 2 - 3 } & Year 2015 & Year 2020 \\
\hline Shanghai & 700 & 1,550 \\
\hline Jiangsu & 4,600 & 9,450 \\
\hline Shandong & 3,000 & 7,000 \\
\hline
\end{tabular}

Offshore wind resource assessment accuracy decides directly the development of offshore wind farm. It is the precondition for the development of wind power and basis for wind farm site selection, layout, wind turbine selection, power budget estimation and economic foundation. Statistically, offshore sea wind speed at $10 \mathrm{~km}$ is usually about $25 \%$ higher than the coastal land and the final account for about $70 \%$. The smaller error of the wind resource assessment can be amplified, which leads to the huge loss of economic benefits.

Onshore wind resource assessment technology is very mature. Many countries have carried out the relevant national standards. The offshore wind resource assessment methods are great similarity with onshore wind resource assessment ones, such as the wind data, sorting and proofreading, unreasonable data filtering, data correction. Furthermore, many other factors should be considered about the offshore wind resources assessment as follows.

1) The influence of the wake distance and scope.

2) Ocean climate impact on wind turbine maintenance and availability.

3) The influence of temperature and water temperature on offshore wind speed range and the influence of wake effect distance.

4) Water level changes on the influence of the vertical distribution of wind speed.

5) The changing rule of the sea breeze day and night.

The assessment methods can be divided into macroscopic wind resource assessment and micro wind resource assessment considering different service objects, purposes, functions and methods. Macro wind resource assessment is carried out in the planning stage, whose main application objects are the government and the management department. The wind resource assessment result is the basis for national macro decision-making, industry development and an important scientific for the development planning. Micro wind resource assessment is carried out in the feasibility study stage, whose main application objects are wind power development management and approval of the department, the wind power developers. The analysis results will be the basis of wind turbine selection, layout, installed capacity and economic estimates. At present the wind power technology in European, such as Denmark, and Sweden, has been advanced in offshore wind energy resource assessment, such as Denmark, and Sweden. They have set up preliminarily multiple fan wake model and revealed the influence of tidal sea wind speed, wind day and night change law. The assessment of offshore wind power resource is enlightened by these technologies in China. 


\section{Wind farm sitting}

As for the particularity of the offshore wind farm, the construction environment is also an important factor when a suitable offshore wind farm site is selected.

Some factors should be considered, such as marine planning, environmental planning, and military planning as for the complexity of the marine environment. If other factors, such as wind meteorological, hydrological geology, construction planning are involved, the weighted score method is adopted according to the important degree of these constraint factors. The constraint factors are shown in TABLE III.

TABLE III. CONSTRAINT FACTORS OF OFFSHORE WIND FARM LOCATION

\begin{tabular}{|c|c|c|}
\hline \multicolumn{2}{|c|}{$\begin{array}{c}\text { Constraints Constraints in } \\
\text { detail }\end{array}$} & Detail description \\
\hline \multirow[t]{4}{*}{$\begin{array}{l}\text { One } \\
\text { ticket } \\
\text { veto }\end{array}$} & $\begin{array}{c}\text { Sea area planni } \\
\mathrm{ng}\end{array}$ & $\begin{array}{c}\text { Port; Channel; } \\
\text { Anchorage; Oil and gas } \\
\text { fields. Historical sites; } \\
\text { Fisheries reserve, etc. }\end{array}$ \\
\hline & $\begin{array}{c}\text { Offshore constr } \\
\text { uction }\end{array}$ & $\begin{array}{c}\text { Offshore drilling } \\
\text { platform; Oil and gas } \\
\text { pipelines; Marine cable; } \\
\text { AIDS to navigation, } \\
\text { buoys, etc. }\end{array}$ \\
\hline & $\begin{array}{c}\text { Environmental } \\
\text { project }\end{array}$ & $\begin{array}{l}\text { Nature reserve; Activity } \\
\text { of animals (including } \\
\text { migration path), etc. }\end{array}$ \\
\hline & $\begin{array}{c}\text { Military plannin } \\
\mathrm{g}\end{array}$ & $\begin{array}{c}\text { Military activity area; } \\
\text { Military facilities area, } \\
\text { etc. }\end{array}$ \\
\hline \multirow[t]{4}{*}{$\begin{array}{l}\text { Negotia } \\
\text { ble } \\
\text { factors }\end{array}$} & Wind weather & $\begin{array}{l}\text { The wind resource } \\
\text { situation; Air flow; } \\
\text { Temperature, humidity, } \\
\text { and salinity; The storm } \\
\text { tide, typhoon and other } \\
\text { meteorological disasters. }\end{array}$ \\
\hline & Hydrogeology & $\begin{array}{l}\text { Earthquake and other } \\
\text { geological disasters; } \\
\text { Deep sea; Shore } \\
\text { protection; Estuaries, } \\
\text { and drain; The seabed } \\
\text { sediment, etc. }\end{array}$ \\
\hline & $\begin{array}{l}\text { Construction } \\
\text { planning }\end{array}$ & $\begin{array}{l}\text { Highway; Railway; } \\
\text { Bridge; Airport; Pier; } \\
\text { Substation; Electricity } \\
\text { access system, etc. }\end{array}$ \\
\hline & $\begin{array}{c}\text { Environmental } \\
\text { constraint }\end{array}$ & $\begin{array}{l}\text { The negative impact of } \\
\text { tourism, fisheries and } \\
\text { coastal defense, etc. }\end{array}$ \\
\hline
\end{tabular}

\section{THE KEY TECHNOLOGY IN THE OFFSHORE WIND FARM OPERATION PROCESS}

\section{A. Offshore wind farm power grid system}

The wind farm is more and more far away from the coast and this leads to the technical requirements of power grid is higher and higher. As to offshore wind farms, the electric network structure and power transmission mode are hot topics all over the world[4]. The collector system consists of wind turbines and substations. The turbines are generally divided into groups and each group uses the star connection or the string type connection. Wind turbines are not equipped with transformers using star connection. However, the string system has independent transformers, which has better stability although this method cost higher. Therefore, the string type connection is usually used in the offshore wind turbines.

Offshore wind power transmission systems are divided into the high voltage AC (HVAC) transmission and high voltage direct current (HVDC) transmission[5]. Generally it takes HAVC transmission way when the wind farm is small and close to the coast. The technology of the HVAC transmission is more mature and cheaper than that of HVDC transmission. However, the long distance communication cable affects the charging current and this limits the transmission capacity and transmission distance. Therefore, the traditional way of communication transmission cannot meet the demand of interconnection of wind farm considering the increase of installed scale and the distance to the coast. The light HVDC transmission mode based on VSC (voltage source converter) suits wind farms and main communication access system. The light HVDC transmission project based on VSC has been built in some countries, such as Tjaereborg wind field in Denmark and Sweden Gotland wind field.

\section{B. Remote monitoring system}

Offshore wind power generators are generally operated under the condition of bad environments due to the complexity of the marine environment. The maintenance engineers need enter the cabins to inspect and repair the equipment faults. This behavior will affect the normally scheduling and operation of the wind turbines. Thus, a remote monitoring and fault diagnosis system is developed to obtain the operating status of the wind turbine timely and extract the fault feature, The system consists of machine, communications lines, protocols, upper monitor, network monitoring, machine parts, shown in Fig. 1. The state of wind turbines, data and fault information are collected by the lower machine (generally for the microprocessor). Then the information is sent to the upper machine through special communication interface. The engineers or operators can monitor the operating status of wind turbines through the human-computer interface. Other relevant engineers also can monitor and check the operation of wind farms in real time through the network. 


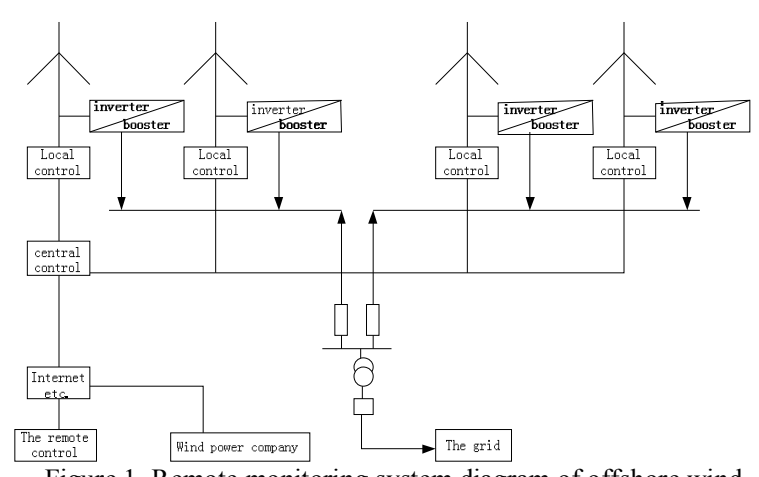

Figure 1. Remote monitoring system diagram of offshore wind power.

\section{The running maintenance of offshore wind turbines}

The equipment failure rate is higher when the equipment is in operation stage. The malfunctions exist mostly in generator, gear box, mechanical transmission system, blade and control system, etc. The common wind turbine maintenance scheme includes mainly regular maintenance, downtime, and condition monitoring[6]. Regular maintenance can better guarantee the safe and stable operation of wind turbines. Nevertheless, the project costs too much because the regular replacement can lead to the waste of resources and the condition of the sea weather varies badly. The power loss caused by the idle generators is huge, so that it can't be applied to the maintenance of offshore wind turbines. The real-time monitoring can be realized by remote monitoring system in this paper. The fault information is responded in time, so that the cost of preventive maintenance and downtime increases will be avoided. At the same time the real-time monitoring also requires timeliness and accuracy of the whole remote fault monitoring system.

\section{CONCLUSIONS}

The development of offshore wind farms in China is still in the exploratory stage. The test of moisture, waves, wind and salt fog put forward higher requirements on the safe operation and the development of offshore wind farms in China. Offshore wind power industry has boomed as the departments of government continuously strengthen and guarantee the development of offshore wind. It is significant for offshore wind power to alleviate the global resources shortage although the offshore wind power is an attempt with high risk.

\section{ACKNOWLEDGMENT}

This work was financially supported by Shanghai Municipal Science and Technology Commission (No.11DZ1200207), and Innovation Program of Shanghai Municipal Education Commission (NO.13YZ139).

\section{REFERENCES}

[1] X. Su, European offshore wind development report in the first half of 2013 [J]. Journal of wind energy, No. 8 (2013), p. 32.

[2] Z. Wang, X. Yu, S. Liu, S. Xia, in: Large wind turbine condition monitoring and intelligent fault diagnosis (In Chinese)[M]. Shanghai: Shanghai Jiaotong University Press (2013).

[3] X. Wang, jing-jing xu, etc. Shanghai coastal wind energy resource assessment [J]. Journal of Marine technology, Vol. 31, No. 1 (2013), p. 108.

[4] H. Lin, Y. Guo, B. Sun, etc. Some key technologies of the offshore wind review [J]. Journal of southeast university, No. 9 (2011), p. 883.

[5] Z. Zhang. Offshore wind farm power transmission technology research [J]. Electric technology, No. 9 (2012), p. 5.

[6] X. Zheng, C.Ye, Yang. Research and development of offshore wind farm operation [J]. Power grid and clean energy, No.28 (2012), p. 91.

[7] X. Su, European offshore wind development report in the first half of 2012 [J]. Journal of wind energy, No.8 (2012), p. 32.

[8] F. Yang, y. Zhang, X. Ge, L. Liu, M. Yin. Germany offshore wind VSC - HVDC technology analysis [J]. Power System and Clean Energy, No.28 (2012), p. 64.

[9] X.Yan. Danish offshore wind power development and experience learning [J]. China market, No.13 (2010), p. 82.

[10] S K Chaudhary, R Teodorescu, P Rodriguez. Wind farm grid Integration using VSC based HVDC transmission-an overview[C]//IEEE Energy 2030,Atlanta,USA,Nov,2008. 